\title{
Evaluation of care for traffic accidents victims made by on duty emergency physicians and surgeons in the emergency room
}

\section{Avaliação do atendimento às vítimas de acidentes de trânsito por plantonista clínico e cirurgião na sala de emergência hospitalar}

Vlaudimir Dias Marques"; Mauricio Medeiros lemos ${ }^{1}$; Cesar Orlando Peralta Bandeira, ACbC-PR ${ }^{1}$; Amélia Cristina Seidel ${ }^{1}$; Sandra Maria Peloso'; Maria Dalva de Barros Carvalho'.

A B S T R A C T

\begin{abstract}
Objective: to evaluate the care for victims of traffic accidents by on call emergency physicians and/or surgeons in the emergency room. Methods: we conducted a retrospective, descriptive and exploratory study on the care for traffic accidents victims in the urban area of Maringá-PR, between July 2013 and July 2014 in reference hospitals. We assessed demographics and vocational training through a questionnaire sent to the attending physicians. Results: of the 688 records evaluated, 99\% of patients had a prehospital Revised Trauma Score of 12. Statistical analysis showed that in the cases conducted by the emergency physicians $(n=187)$, the recording of the Glasgow Coma Scale and the performance of surgical procedures were less common, whereas the recording of blood pressure values was performed in greater numbers when compared with cases led by surgeons $(n=501)$. There was a statistically significant relationship $(p<0.01)$ between the length of hospital stay and surgical specialty, with a greater chance (crude $O R=28$ ) in the period from one to six hours for the group treated by emergency doctors. Most physicians participating in the study were young, with emergency room time of up to one to two years, and with ATLS training. Among those who had attended the ATLS course, 60\% did so in the last four years. Surgeons performed $73 \%$ of hospital treatments. Conclusion: in the care of traffic victims with minor injuries, the Glasgow Coma Scale, the blood pressure levels, the type of treatment in the emergency room and hospital stay had different approaches between emergency physicians and surgeons.
\end{abstract}

Keywords: Accidents, Traffic. General Practitioners. Surgeons. Emergency Medical Services. Evaluation of Research Programs and Tools.

\section{INTRODUCTION}

In recent years, Trauma has become one of the biggest public health problems'. In cases of traffic accidents (TA), thousands of lives are compromised each year, making constant the need for discussion, prevention planning and treatment of these victims ${ }^{2,3}$.

In pre-hospital care provided by the Emergency Trauma Care Integrated Service (SIATE) of the Fire Department, triage and classification of victims are carried out according to the degree of severity, followed by primary care for stabilization of the urgency or emergency condition and later referral to a more complex service for the continuity of treatment ${ }^{4}$.

In Brazil, not all hospital services have qualified professionals for the care of multiple trauma. Any doctor who has professional license can act as an emergency physician ${ }^{5}$. The Resolution 2077/14 of the Federal Medicine Council (CFM) deals with the regulation of the Emergency Hospital, as well as with the design of the medical team and the work system. Its Art. $3^{\text {rd }}$ defines the obligation of care be performed by a doctor, though with no reference as to specialty ${ }^{6}$. In practice, it is observed that the "emergency room" doctor is specializes in internal medicine or general surgery, and should have appropriate skills and knowledge to work in the emergency room. However, the CFM Resolution no 2149/2016 of July 22, 2016, approves the recognition of Emergency Medicine as a medical specialty, and Emergency Medicine as a Medical Practice Area ${ }^{6}$. These new well trained specialists may make a difference with appropriate and safe decisions when acting in emergency settings ${ }^{7}$.

The difference of the specialized training and personality between the internal medicine physician and the surgeon is historical. Bellodi ${ }^{8}$ noted that even today, the stereotypes of these doctors are equivalent,

1 - State University of Maringá (UEM), Health Sciences Center, Post-Graduate Program in Health Sciences, Maringa, Parana State, Brazil. 
despite all the changes over time. To clinicians, formerly physicists, the appreciation of the mind, and to surgeons, the barbers, the risky procedures ${ }^{8,9}$. In another study with a group of Brazilian residents, the same author identified, amongst other variables, personality traits, the clinicians being quieter, detaildriven and more interested in interpersonal contact, while the surgeons are faster, more impulsive and more aggressive ${ }^{10}$.

It is possible that this type of aggressive and impulsive personality is a decisive factor in choosing training courses that enable the surgeon to care for polytrauma patients. This formation goal tends to make this professional the most suitable and most qualified for this type of service, differentiating him/ her from those with other interests.

Considering the studies showing different personality characteristics between clinicians and surgeon as a factor for specific training, it is fair to raise the following issue: "Is there a difference in trauma care provided by the emergency physician and the surgeon?". So far, there are no references in the literature comparing the polytrauma patient approach with the kind of specialty of the emergency room doctor.

The objectives of this study were to evaluate the care of victims of traffic accidents by emergency physicians and / or surgeons in the emergency room and to identify the emergency training of such doctors.

\section{METHODS}

We conducted an observational, documental, retrospective, descriptive and exploratory study, with traffic accident (TA) victims in urban areas, over 18 years of age, of both gender, attended by the prehospital rescue team - SIATE - in Maringa, PR, and sent to reference hospitals in the period from July 2013 to July 2014.

We obtained data from the site www. bombeiroscascavel.com.br, collecting the records made by Maringa Fire Department $V$ Division, containing the name, day, time and type of event and the destination hospital. With this list, we then obtained the hospital records of patients and Rescue Attendance Reports (RAR).

The variables analyzed in this study were: type of medical specialty of the professional who attended the victim, recording of Glasgow Coma Scale (GCS) and of levels of Systemic Blood Pressure (SBP), procedures carried out by the professional and hospital stay.

As non-surgical procedures, we considered analgesia, clinical observation, neurological observation and sole evaluation; and as surgical procedures, analgesia + dressing, analgesia + immobilization, dressing, immobilization and suture.

We applied a questionnaire to doctors working at the emergency rooms to characterize the professionals as for demographic variables, professional training and difficulties in trauma patient care.

We ordered data in spreadsheets (Microsoft Excel for Mac 2011 Version 14.6.0) and analyzed them in a descriptive way through absolute numbers and percentages. We applied the chi-square test, uni and multivariate analysis with the software SAS 9.4, considering $\mathrm{p} \leq 0.05$ as significant.

This study was approved by the Standing Committee on Human Research of the State University of Maringa (COPEP-UEM), opinion № 37686114.8.0000.0.

\section{RESULTS}

During the study period, 45 physicians (17 clinicians and 28 surgeons) were responsible for the care of 688 TA victims (177 attendances by emergency physicians and 501 by surgeons).

According to univariate analysis, there were statistically significant differences between variables related to medical specialty. The results are shown in Table 1. 
GCS values were recorded in 345 evaluations made by surgeons and in 56 cases treated by clinicians. In 287 records, GCS recording was absent. The chance of a clinician not recording the GCS was 5.2 times higher than the surgeon's.

SBP values were recorded in 137 evaluations made by surgeons and in 129 by clinicians, lacking in 422 charts. The chance of a clinician recording SBP was six times higher than the surgeon's.

Hospital stay greater than six hours occurred in 10\% ( $n=69)$ of treated cases; $99 \%$ of these visits were performed by surgeons. The chance of a clinician discharging a patient before six hours of observation was 28 times greater than the surgeon's.

Regarding the type of treatment provided in the emergency room, in $75 \%(n=515)$ of cases "nonsurgical" procedures were performed. The chance of a clinician performing a non-surgical procedure was 1.7 times greater than the surgeon's.

We also applied multivariate analysis and found a statistical correlation between variables, whose results are shown in Table 2.

As for the length of stay and type of treatment, we observed that these were not associated factors (Table 3).

Only $40 \%(n=18)$ of physicians responded to the questionnaire, identifying some features shown in Table 4. The profile found in this study were of young doctors, mostly male and Surgeons, 61\% with ER time less than four years and with ATLS training. Of these, $60 \%$ had taken the course less than four years before.

\section{DISCUSSION}

There is no legal requirement in Brazil for the doctor attending the emergency room to be from a clinical or surgical specialty. In this sample, there was a contingent of surgeons greater than clinicians.

In the 688 patient records analyzed, we observed that surgeons have made 501 evaluations and proportionately more surgical procedures than clinicians have. This fact could be justified by the victim having lesions that justify the procedure or by the greater predisposition toward this conduct by the characteristics of the surgeon, such as impulsiveness, quick thinking and aggressiveness in conducts ${ }^{11}$. Surgeons tend to be more practical, objective and like manual activities, often with faster and more concrete results ${ }^{10}$.

From a clinical point of view, the GCS score is an important neurological parameter and practically a synonym of gravity in head trauma (TBI). Scores between 3 and 8 are classified as severe trauma, between 9 and 12 as moderate and between 13 to 15 as mild ${ }^{11}$.

In a study of patients rescued by emergency mobile care service, Souza ${ }^{12}$ reported that despite its importance, GCS was neglected many times, reporting abstention to record this value in $3.2 \%$ of cases. Ribeiro ${ }^{13}$ identified charts without its records in 897 cases (97\% of total) when filled by nurses prehospital, though with no references to notes in hospital care.

In this study, surgeons recorded GCS values in patients' charts at hospital admission more frequently than clinicians did (69\% versus 30\%, respectively). The vast majority of victims assisted (400 - 58\%) had scores between 13 and 15, and only one case presented score of 3 . In $42 \%$ ( $n=287)$ this record was missing, and in some reviewed charts there was a description by the doctor that the victim was conscious, oriented and without motor deficits, inferring a high value for GCS; however, having not been registered, we did not consider it as recorded. This condition could explain the $42 \%$ of absence of GCS records in this sample.

In contrast, in cases reported in medical records $(n=401), 86 \%$ were by surgeons, while only $14 \%$ by emergency physicians. The ATLS advocates the use of the GCS as an objective clinical measure of TBI severity, becoming routine to the doctor in polytrauma care, even in those 
patients without $\mathrm{TBI}{ }^{10}$. This finding is important for the proper evaluation of trauma patients in view of the possibility of unnoticed injuries evolving to a neurosurgical emergency ${ }^{14}$.

Alavarce et al. ${ }^{15}$ found that the SBP measure, besides being simple and easy to execute, should be carried out in all health care evaluations, independently of the attending physician specialty. In this study, we observed that surgeons recorded SBP values at hospital admission fewer times than clinicians did $(27 \%$ versus $69 \%$ ). A previous study found SBP recording in $85.3 \%$ of cases evaluated, differing from the latter because only 39\% ( $n=266)$ of cases were recorded at admission, however, according to pre-hospital care data, SBP was recorded in $97 \%$ of case $^{16}$.

SBP levels are an important physiological parameter in the evaluation of polytrauma patients, depending on the types of injuries found, translating volume loss (bleeding). Although not reflecting the actual state of tissue perfusion, its systematic measurement is advocated ${ }^{17}$. The estimated blood loss based on the initial condition of patients with multisystem trauma can be classified into classes (I, II, III and IV). Each has signs and symptoms according to the degree of volume loss. Classes I and II comprise an approximate blood loss of up to 15\% (volume = $750 \mathrm{ml}$ ) and between 15 and 20\% (volume $=750$ to $1500 \mathrm{ml})$, respectively. On physical examination, one does not observe a drop in SBP levels in these two classes. This fall will be identified in shock, i.e., classes III and IV ${ }^{11,18}$.
In this study, most patients were victims of minor injuries and t-RTS 12 (corrected RTS 7.8408), with no evidence of hemorrhagic shock (mean systolic SBP $127 \mathrm{mmHg}$ ), both in the prehospital assessment and at arrival at the emergency room. This could justify the lack of importance given by the surgeon to the measurement of blood pressure at that time and consequently to its recording.

Regarding the length of stay, we found that 621 patients (90.3\%) remained for a time shorter or equal to six hours, and the majority $(n=435)$ was attended by surgeons. We observed a greater chance of an emergency physician releasing the patient before six hours of observation. The relevance of this finding $(O R=28)$ did not translate into better type of service or professional negligence. The result in question might be justified by the clinical picture and type of injury presented by the patient (t-RTS 12 and CODE 1 SIATE) opposing the medical specialty.

Vieira et $a l .{ }^{19}$, in a study conducted in Sergipe, showed that $76 \%$ of victims treated had length of stay of up to 12 hours. In another study conducted in Ribeirão Preto, Coelho et al. ${ }^{20}$ reported that $39.8 \%$ of patients remained for less than six hours and $27.4 \%$, between 24 and 30 hours, with no mention to the type of specialty.

Statistical analysis showed that there was an association between length of stay and surgical specialty (Tables 1 and 2). However, when related to the type of treatment, there was no statistical association, that is, the chance of an emergency

Table 1. Univariate logistic regression model of variables related to medical specialty.

\begin{tabular}{|c|c|c|c|c|c|c|}
\hline Variable & Categories & $\begin{array}{c}\text { Surgeons } \\
n=501(73 \%)\end{array}$ & $\begin{array}{c}\text { Clinicians } \\
\mathrm{n}=187(37 \%)\end{array}$ & Gross OR & $95 \% \mathrm{Cl}$ & p-value \\
\hline Glasgow Coma scale & $\begin{array}{l}\text { Not recorded } \\
\text { Recorded }\end{array}$ & $\begin{array}{l}156 \\
345\end{array}$ & $\begin{array}{l}131 \\
056\end{array}$ & $\begin{array}{c}5.2 \\
1\end{array}$ & {$[3.589 ; 7.452]$} & $<0.001$ \\
\hline Systemic Blood Pressure & $\begin{array}{l}\text { Not recorded } \\
\text { Recorded }\end{array}$ & $\begin{array}{l}364 \\
137\end{array}$ & $\begin{array}{l}058 \\
129\end{array}$ & $\begin{array}{l}1 \\
6\end{array}$ & {$[4,098 ; 8.547]$} & $<0.001$ \\
\hline Type of treatment & $\begin{array}{l}\text { Non-surgical } \\
\text { Surgical }\end{array}$ & $\begin{array}{l}362 \\
139\end{array}$ & $\begin{array}{c}153 \\
34\end{array}$ & $\begin{array}{c}1.7 \\
1\end{array}$ & {$[1.135 ; 2.630]$} & 0.0107 \\
\hline
\end{tabular}

OR: odds-ratio. Cl: confidence interval. p-value: Chi-square test of Mantel-Haenszel. 
Table 2. Multivariate logistic regression model of the variables related to clinical specialty.

\begin{tabular}{|c|c|c|c|}
\hline Variable & Adjusted OR & $95 \% \mathrm{Cl}$ & $p$-value \\
\hline GCS recording & 7.509 & {$[4.818 ; 11.702]$} & $<0.001$ \\
\hline SBP recording & 8.33 & {$[5.347 ; 12.987]$} & $<0.001$ \\
\hline$<6$-hour hospital stay & 15.969 & {$[2.102 ; 121.30]$} & 0.0074 \\
\hline Type of treatment: non-surgical & 1.696 & {$[1.035 ; 2.781]$} & 0.0107 \\
\hline
\end{tabular}

Or: odds-ratio. Cl: confidence interval. p value: Chi-square test of Mantel-Haenszel. GCS= Glasgow Coma scale. SBP=Systemic Blood Pressure.

physician performing a non-surgical procedure in hospital stays shorter than or equal to six hours was similar to a surgeon's (Table 3 ). Only $18 \%$ of care provided by clinicians needed surgical treatment in the emergency room, while for surgeons that number was $28 \%$, which raised the suspicion of different complexity and time of stay, corroborating th significant finding (OR 28) mentioned above.

The results of the questionnaire applied to attending physicians (Table 3) showed that $89 \%$ of respondents were male, aged between 25 and 60 years and had surgical specialty. Most $(50 \%)$ had time of ER over three years, and 39\% of respondents had had ATLS training less than one year before.

Campos and Senger ${ }^{21}$ reported that $31.7 \%$ of graduates worked in emergency services independently of being enrolled or not in some medical residency program. The easy insertion in these services pointed out the importance of proper training for care in this type of situation. Hamamoto ${ }^{22}$ and Pego-Fernandes ${ }^{23}$ reported the unpreparedness of recent graduates and the disorganization of the health care system, which hampers emergency care in public hospitals.

Still on ATLS, $81 \%$ of surgeons attended this training, while for the emergency physicians this percentage was $50 \%$. This result suggests the initial hypothesis of this work, that surgeons are more interested in training for trauma care due to their training background and personality. Brito et al. ${ }^{24}$ stated that training is of utmost importance for the improvement of professional performance, both individually and as a team, which corroborates the pressing need of the professional, regardless of specialty, to train in the respective field, besides making the professional feel more secure and able to provide adequate care ${ }^{25}$.

For $13(72 \%)$ physicians, technical training was considered sufficient, and $89 \%$ reported feeling safe in the diagnosis and treatment of multiple trauma victims. However, $89 \%$ of respondents said trauma care requires specialized training. This need of respondents goes against the principle of the impact of ATLS training for trauma care, which says that students may retain the course techniques and procedures for at least six years. According to the ATLS, this is the most significant impact of all ${ }^{11}$. All 18 respondents consider care protocols o be extremely important in the service.

Not all doctors who were part of the clinical staff of the emergency service in the hospitals

Table 3. Correlation as to the type of treatment and length of stay.

Type of treatment

\begin{tabular}{ccccc} 
Lenght of stay & Non-surgical & Surgical & Gross OR & $95 \% \mathrm{Cl}$ \\
\hline$\leq 6 \mathrm{~h}$ & 467 & 154 & 1 & \\
$>6 \mathrm{~h}$ & 48 & 19 & 1.2004 & {$[0.6846 ; 2.1048]$} \\
\hline
\end{tabular}

Or: odds-ratio. Cl: confidence interval. p-value: Chi-square test of Mantel-Haenszel. 
Table 4 - questionnaire variables applied to physicians $(n=18)$

\begin{tabular}{|c|c|c|c|}
\hline \multirow[t]{2}{*}{ Variables } & \multirow[t]{2}{*}{ Categories } & \multicolumn{2}{|c|}{ Frequency } \\
\hline & & $\mathrm{n}$ & $(\%)$ \\
\hline \multirow{2}{*}{ Gender } & Male & 16 & 89 \\
\hline & Female & 02 & 11 \\
\hline \multirow{4}{*}{ Age } & $25-30$ & 09 & 50 \\
\hline & $31-40$ & 05 & 28 \\
\hline & $41-50$ & 01 & 05 \\
\hline & $51-60$ & 03 & 17 \\
\hline \multirow{2}{*}{ Specialty } & Surgical & 16 & 89 \\
\hline & Clinical & 02 & 11 \\
\hline \multirow{5}{*}{ Time in emergency room } & $<1$ year & 0 & 0 \\
\hline & 1 to 2 years & 06 & 33 \\
\hline & 2 to 3 years & 03 & 17 \\
\hline & 3 to 4 years & 02 & 11 \\
\hline & $>4$ years & 07 & 39 \\
\hline \multirow{6}{*}{ Time since ATLS attendance } & not held & 04 & 22 \\
\hline & $<1$ year & 07 & 39 \\
\hline & 1 to 2 years & 02 & 11 \\
\hline & 2 to 3 years & 01 & 05 \\
\hline & 3 to 4 years & 01 & 05 \\
\hline & $>4$ years & 03 & 17 \\
\hline \multirow{3}{*}{ Technical training believed to be: } & Enough & 13 & 72 \\
\hline & Insufficient & 04 & 22 \\
\hline & Didn't say & 01 & 06 \\
\hline \multirow{2}{*}{$\begin{array}{l}\text { Security in the diagnosis of "imminent risk of life" in a trauma } \\
\text { victim }\end{array}$} & No & 0 & 0 \\
\hline & Yes & 18 & 100 \\
\hline \multirow{2}{*}{$\begin{array}{l}\text { Security to perform necessary medical procedures to treat a } \\
\text { trauma victim }\end{array}$} & No & 02 & 11 \\
\hline & Yes & 16 & 89 \\
\hline \multirow{2}{*}{ Believe one need specialized training for trauma care } & No & 02 & 11 \\
\hline & Yes & 16 & 89 \\
\hline \multirow{2}{*}{ Believe protocols for trauma care are necessary } & No & 0 & 0 \\
\hline & Yes & 18 & 100 \\
\hline
\end{tabular}

ATLS: Advanced Trauma Life Support.

studied answered the questionnaire, only $51 \%$ $(n=18)$ returning. This made it difficult the analysis of some variables. However, the results showed the need to implement care protocols at the hospital level for multiple trauma patients and to encourage the training of medical professionals involved in this type of care

Data from this study indicated a significant difference in care of trauma victims between clinical and surgical specialists. We did not assess the quality of care, but the focal differences in trauma care priorities. This result raises a reflection and discussion about a pressing need now, that is, the figure of the expert in emergency care in the Emergency Units. Differences in medical care provided to victims of trauma depending on the medical specialty are unacceptable. However, the training, even in renowned courses, does not prepare the professional the same way a medical 
residency in the area does. This conclusion is explained in the speech of professionals when they say they feel secure as to their capacity to diagnose and treat multiple trauma victims, but at the same time, they claim to need specialized training in trauma care. It is essential that the competent bodies and associations establish policies that allow emergency healthcare institutions to hire medical experts in the field. This would ensure a safe care, for both the patients who are attended by skilled professionals, and for the professionals who, due to their training, perform the activities with confidence, dynamism and efficiency.

\title{
R E S U M O
}

\begin{abstract}
Objetivo: avaliar o atendimento às vítimas de acidentes de trânsito por médicos plantonistas cirurgiões e/ou clínicos na sala de emergência hospitalar. Métodos: estudo retrospectivo, descritivo e exploratório do atendimento às vítimas de acidentes de trânsito da área urbana de Maringá-PR, entre julho de 2013 e julho de 2014, em hospitais referenciados. Questionário aplicado aos médicos plantonistas avaliou dados demográficos e a formação profissional. Resultados: dos 688 prontuários avaliados, 99\% apresentavam Revised Trauma Score pré-hospitalar de 12. Análise estatística mostrou que nos atendimentos feitos por Clínicos ( $n=187)$, a anotação dos escores da Escala de Coma de Glasgow e a realização de procedimentos cirúrgicos foram feitas em menor número e, em contrapartida, a anotação dos valores de pressão arterial sistêmica foi realizada em maior número quando comparados com atendimentos feitos por Cirurgiões $(n=501)$. Houve relação estatisticamente significativa $(p<0,01)$ entre o tempo de permanência hospitalar e a especialidade cirúrgica, com maior chance (OR bruta=28) observada no período de uma a seis horas para o grupo atendido pelos Clínicos. A maioria dos plantonistas que participaram do estudo eram jovens, com tempo de atividade em sala de emergência hospitalar de um a dois anos e com capacitação no curso do ATLS. Entre os que participaram do curso do ATLS, $60 \%$ o fizeram nos últimos quatro anos. Cirurgiões realizaram $73 \%$ dos atendimentos hospitalares. Conclusão: nos atendimentos às vítimas de trânsito com lesões leves, a Escala de Coma de Glasgow, os níveis de pressão arterial sistêmica, o tipo de tratamento na sala de emergência e o tempo de internação hospitalar tiveram abordagens diferentes entre Clínicos e Cirurgiões.
\end{abstract}

Descritores: Acidentes de Trânsito. Clínicos Gerais. Cirurgiões. Serviços Médicos de Emergência. Avaliação de Programas e Instrumentos de Pesquisa.

\section{REFERENCES}

1. Carvalho ICCM, Saraiva IS. Perfil das vítimas de trauma atendidas pelo serviço de atendimento móvel de urgência. R Interd. 2015;8(1):137-48.

2. Waiselfisz JJ. Mapa da violência 2013: acidentes de trânsito e motocicletas [Internet]. Rio de Janeiro: CEBELA; 2013 [citado 2016 Nov. 03]. Disponível em: http://www.mapadaviolencia.org.br/pdf2013/ mapa2013_trânsito.pdf

3. Malta DC, Andrade SSCA, Gomes N, Silva MMA, Morais Neto OL, Reis $A A C$, et al. Injuries from traffic accidents and use of protection equipment in the Brazilian population, according to a population-based study. Ciên Saúde Coletiva. 2016;21(2):399-410.

4. Campos AL. Atendimento de emergência realizado por profissionais de enfermagem, médico, bombeiros e demais profissionais treinados a vítimas de acidentes e catástrofes. Rev Med Saúde Brasília. 2015;4(1):84-96.

5. Sousa MV, d'Acampora AJ, Muller MR, Moritz RD, Kotzias Neto A. Os serviços de emergên- cias hospitalares do estado de Santa Catarina: um estudo exploratório. ACM Arq Catarin Med. 2009;38(3):86-95.

6. Conselho Federal de Medicina. Dispõe sobre a normatização do funcionamento dos Serviços Hospitalares de Urgência e Emergência, bem como do dimensionamento da equipe médica e do sistema de trabalho. Resolução no 2077, de 24 de julho de 2014 [citado 2016 fev. 28]. Disponível em: http:// portal.cfm.org.br/images/PDF/resolucao2077.pdf.

7. Conselho Federal de Medicina. Homologa a Portaria CME no 02/2016, que aprova a relação de especialidades e áreas de atuação médicas aprovadas pela Comissão Mista de Especialidades. Resolução $n^{\circ} 2.149$, de 22 de julho de 2016 [citado 2016 set 24]. Disponível em: http://www.portalmedico.org. br/resolucoes/CFM/2016/2149_2016.pdf

8. Bellodi PL. Vocação, profissão e personalidade: uma contribuição na área médica através do psicodiagnóstico de Rorschach. Aval Psicol. 2006;5(2):269-73.

9. Bellodi PL. The general practitioner and the surgeon: stereotypes and medical specialties. Rev Hosp Clin. 2004; 59(1):15-24. 
10. Bellodi PL. Surgery or general medicine - a study of the reasons underlying the choice of medical specialty. São Paulo Med J. 2004;122(3):81-6.

11. Suporte Avançado de Vida no Trauma. ATLS. Manual do Curso de Alunos. 9. ed. Colégio Americano de Cirurgiões. Comitê de Trauma: Chicago; 2012

12. Souza SG. Service Mobile Service Urgent: trauma brain Injury Index in traffic accident victims in a city of the interior of Paraiba. INTESA - Informativo Técnico do Semiárido. 2015;9(2):30-3 [cited 2016 feb. 21]. Available from: http://www.gvaa. com.br/revista/index.php/INTESA

13. Ribeiro AC, Silva YB. Enfermagem pré-hospitalar no suporte básico de vida: postulados ético-legais da profissão. Cogitare Enferm. 2016;21(1):1-8.

14. Silva F, Boes AA, Lazzari DD, Busana JA, Nascimento ERP, Jung W. Victims of trauma by motorcycle accident attended in urgency mobile service. Rev Enferm UFPI. 2015;4(3):71-8.

15. Alavarce DC, Pierin AMG, Mion Jr D. A pressão arterial está sendo medida? Rev Esc Enf USP. 2000;34(1):84-90.

16. Brasil. Ministério da Saúde. Portaria no 1863, de 29 de setembro de 2003. Institui a Política Nacional de Atenção às Urgências, a ser implantada em todas as unidades federadas, respeitadas as competências das três esferas de gestão [Internet]. [acesso em 2016 fev. 22]. Disponível em: http://bvsms.saude.gov.br/bvs/saudelegis/ gm/2003/prt1863_26_09_2003.html

17. Colégio Brasileiro de Cirurgiões. Programa de auto-avaliação em Cirurgia: trauma [citado em 2016 mar. 02]. Disponível em: https://cbc.org.br/wp-content/uploads/2013/05/Ano1-II.Trauma.pdf

18. Felice CD, Susin CF, Costabeber AM, Rodrigues AT, Beck MO, Hertz E. Choque: diagnóstico e tratamento na emergência. Rev AMRIGS. 2011;55(2):179-96.
19. Vieira RCA, Hora EC, Oliveira DV, Vaez AC. Levantamento epidemiológico dos acidentes motociclísticos atendidos em um Centro de Referência ao Trauma de Sergipe. Rev Esc Enferm USP. 2011;45(6):1359-63.

20. Coelho MF, Chaves LDP, Anselmi ML, Hayashida M, Santos CB. Analysis of the organizational aspects of a Clinical Emergency Department: a study in a general hospital in Ribeirão Preto, SP, Brazil. Rev Latino Am Enferm. 2010;18(4):770-7.

21. Campos MCG, Senger MH. The work of recently graduated physicians in emergency services. Ver Soc Bras Clin Med. 2013;11(4):1-5.

22. Hamamoto Filho PT. Ligas Acadêmicas: motivações e críticas a propósito de um repensar necessário. Rev Bras Educ Med. 2011;35(4):535-43.

23. Pego-Fernandes PM, Mariani AW. Medical teaching beyond graduation: undergraduate study groups [editorial]. São Paulo Med J. 2010;128(5):257-8.

24. Brito MY, Ziviani F, Oliveira JLR, Christino JMM. Estudo sobre a importância da capacitação do servidor administrativo do Hospital das Clínicas da Universidade Federal de Goiás. RAHIS. 2013;10(2):65-77.

25. Divino EA, Pereira QLC, Siqueira HCH. Qualification of a mobile pre-hospital care team: the need and the importance of a continuous education in the professionals' point of view. Rev Min Enferm. 2009;13(3):365-71.

Received in: 14/07/2016

Accepted for publication: 11/10/2016

Conflict of interest: none.

Source of funding: none.

\section{Mailing address:}

Vlaudimir Dias Marques

E-mail: vdmarques@uem.br / vlaud@bol.com.br 